\title{
Effects of Anti-Allergy Drugs on Th1 Cell and Th2 Cell Development Mediated by Langerhans Cells
}

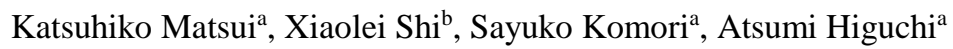 \\ a Department of Clinical Immunology, Meiji Pharmaceutical University, Tokyo, Japan; ${ }^{b}$ College of Food Science and \\ Engineering, Jilin University, Changchun, China
}

Corresponding author: Katsuhiko Matsui, Ph.D., Department of Clinical Immunology, Meiji Pharmaceutical University; 2-522-1
Noshio, Kiyose, Tokyo, Japan 204-8588; TEL: (+81)-42-495-8677; e-mail: kmatsui@ @y-pharm.ac.jp

Received, July 6, 2020; Revised, October 26, 2020; Accepted, October 27, 2020; Published, October 30, 2020

\begin{abstract}
Background: Langerhans cells (LCs) are involved in T helper type 1 (Th1) or T helper type 2 (Th2) immune responses. We examined the effects of various anti-allergy drugs against the Th2 cell development by LCs. Methods: The expression of cell surface molecules on LCs was investigated using RT-PCR. The effects of anti-allergy drugs on T-cell immunoglobulin and mucin domain-containing protein (TIM)-4 expression in LCs were examined to predict whether they would inhibit Th2 cell development. Next, mice were primed via the hind footpad with ovalbumin (OVA)-pulsed LCs that had been treated with selected anti-allergy drugs, cyproheptadine, promethazine, emedastine and loratadine. After 5 days, the cytokine response in the popliteal lymph nodes was investigated by enzyme-linked immunosorbent assay. The therapeutic effects of a finally selected drug, emedastine on atopic dermatitis (AD) were assessed using in NC/Nga mice. Results: OVA peptide-pulsed LCs that had been treated with each drug and injected into the hind footpads of mice inhibited Th2 cell development, as represented by down-regulation of interleukin (IL)-4 production. The LCs that had been treated with emedastine also inhibited Th1 cell development, as represented by down-regulation of interferon (IFN)- $\gamma$ production. This was accompanied by suppression of CD40 expression in LCs. Topical application of emedastine significantly suppressed the increase in the skin severity score in $\mathrm{NC} / \mathrm{Nga}$ mice. This suppressive effect was associated with a decrease in the production of IFN- $\gamma$ and IL-4 in auricular lymph node cells. Conclusions: Topical application of emedastine may be beneficial in AD-like skin lesions by inhibiting both Th1 cell and Th2 cell development mediated by LCs.
\end{abstract}

\section{INTRODUCTION}

Langerhans cells (LCs) are a subpopulation of bone marrow-derived dendritic cells (DC). They are antigen-presenting cells (APCs), capable of internalizing and processing antigen (1). Because they reside in the epithelium of the skin and mucous membranes, they may be the primary target cells for antigens entering the skin, oral mucosa and airways (2-5). After antigen uptake they migrate to regional lymph nodes where peptides, in the context of major histocompatibility complex (MHC) class II molecules, are presented to $\mathrm{T}$ helper (Th) cells with appropriate Th cell receptors. This first signal to the Th cells, together with a second signal, delivered in part by the interaction between CD80 and CD86 molecules on the LCs and CD28 on the Th cells, results in activation of Th cells $(6,7)$. Furthermore, LCs work as the primary orchestrators in polarization towards Th type 1 (Th1) or Th type 2 (Th2) immune responses. The nature of the polarization is influenced by a number of factors and in particular, development of Th2 cells producing type 2 cytokines such as interleukin (IL)-4, IL-5 and IL-13 plays pivotal roles in inducing allergic inflammation (8). Therefore, allergic inflammation would be controlled through the regulation of LCs. In our previous study, we demonstrated that LCs treated with josamycin, a 16-membered ring macrolide antibiotic, norfloxacin, a fluoroquinolone antibiotic, and doxycycline, a tetracycline antibiotic, inhibited Th1 cell and/or Th2 cell development (9-11). These results suggested that LCs would be an appropriate target for regulating the development of a Th1- or Th2-prone immune response.

In modern medical care, many anti-allergy drugs are used to control allergic diseases including atopic dermatitis (AD) and/or asthma, and are classified on the basis of their action mechanism 
into 5 types: mediator release inhibitors, histamine $\mathrm{H}_{1}$ antagonists, thromboxane $\mathrm{A}_{2}$ inhibitors, leukotriene receptor antagonists, and Th2 cytokine inhibitors. The histamine $\mathrm{H}_{1}$ antagonists are further classified into classical $\mathrm{H}_{1}$ blockers and second-generation $\mathrm{H}_{1}$ receptor antagonists, and thromboxane $\mathrm{A}_{2}$ inhibitors are classified into thromboxane $\mathrm{A}_{2}$ synthesis inhibitors and thromboxane $A_{2}$ receptor agonists. Although the mechanisms responsible for the pharmacological actions of these anti-allergy drugs have been fully studied, it has not been clarified whether Th1 cell and Th2 cell development is regulated by LCs after treatment with these anti-allergy drugs. In the present study, therefore, we investigated the effects of anti-allergy drugs on LCs in the context of inhibition of Th1 cell and Th2 cell development, and evaluated the effect of topical application of a selected drug on AD-like skin lesions in $\mathrm{NC} / \mathrm{Nga}$ mice.

\section{MATERIALS AND METHODS}

\section{Mice}

Female specific-pathogen-free BALB/c (wild type) mice and DO $11.10 \mathrm{TCR}$ Tg mice (ovalbumin (OVA) 323-339-specific I-A ${ }^{\mathrm{d}}$-restricted T-cell receptor (TCR)-transgenic mice) were obtained from Japan SLC (Hamamatsu, Japan) and the Jackson Laboratory (Bar Harbor, Maine, USA), respectively, and used at the age of 6 to 8 weeks. They were housed in plastic cages with sterilized paper bedding in a clean, air-conditioned room at $24{ }^{\circ} \mathrm{C}$ and allowed free access to a standard laboratory diet and water. All animal procedures were approved by the Guidelines of the Animal Care and Use Committee of Meiji Pharmaceutical University, Tokyo.

\section{Anti-Allergy Drugs}

Montelukast, pranlukast and zafirlukast as leukotriene receptor antagonists were purchased from Cayman Chemical (Ann Arbor, MI, USA). Suplatast tosilate as a Th2 cytokine inhibitor, sodium cromoglicate, tranilast, amlexanox and pemirolast as mediator release inhibitors, ozagrel as a thromboxane $\mathrm{A}_{2}$ synthesis inhibitor, seratrodast as a thromboxane $A_{2}$ receptor antagonist, diphenhydramine as an ethanolamine $\mathrm{H}_{1}$ blocker, chlorpheniramine as a propylamine $\mathrm{H}_{1}$ blocker, cyproheptadine as a piperidine $\mathrm{H}_{1}$ blocker,

promethazine as a phenothiazine $\mathrm{H}_{1}$ blocker, and ketotifen, fexofenadine, epinastine, cetirizine, levocetirizine, emedastine, loratadine, azelastine, mequitazine and ebastine as second-generation $\mathrm{H}_{1}$ receptor antagonists were purchased from Tokyo Chemical Industry (Tokyo, Japan).

\section{Generation of LCs}

Mouse bone marrow cells for generation of LCs were prepared and cultured as described previously (12). Briefly, bone marrow cells from BALB/c mice were cultured in RPMI 10 (RPMI 1640 medium with L-glutamine (Sigma-Aldrich, St. Louis, MO, USA) containing $10 \%$ fetal bovine serum (Sigma-Aldrich), $25 \mathrm{mM}$ Hepes (Sigma-Aldrich), $100 \mathrm{U} / \mathrm{mL}$ penicillin and 100 $\mu \mathrm{g} / \mathrm{mL}$ streptomycin (Gibco RBL, Grand Island, NY, USA)) supplemented with recombinant murine GM-CSF (20 ng/mL; PeproTech, Rocky Hill, NJ, USA), recombinant murine IL-4 $(100 \mathrm{ng} / \mathrm{mL}$; PeproTech) and recombinant human TGF- $\beta 1$ (10 $\mathrm{ng} / \mathrm{mL}$; PeproTech) at $37{ }^{\circ} \mathrm{C}$ in a humidified atmosphere with $5 \% \mathrm{CO}_{2}$. Half of the total volume of the culture medium was changed every $48 \mathrm{~h}$, and 7 days after the beginning of culture, the grown cells were treated with mouse anti-mouse $\mathrm{I}_{-} \mathrm{A}^{\mathrm{d}}$ monoclonal antibody (clone 34-5-3s, mouse IgG2a) (final concentration 1:200; Cedarlane Laboratories, Ontario, Canada) in RPMI 10 for $1 \mathrm{~h}$ on ice. The cells that reacted with anti-I-A ${ }^{\mathrm{d}}$ antibody were then purified using a CELLection Pan Mouse IgG Kit (Invitrogen Dynal AS, Oslo, Norway) and used as LCs. LCs, identified as I-A ${ }^{\mathrm{d}}$-positive cells, were purified to around $95 \%$ purity as determined by flow cytometry.

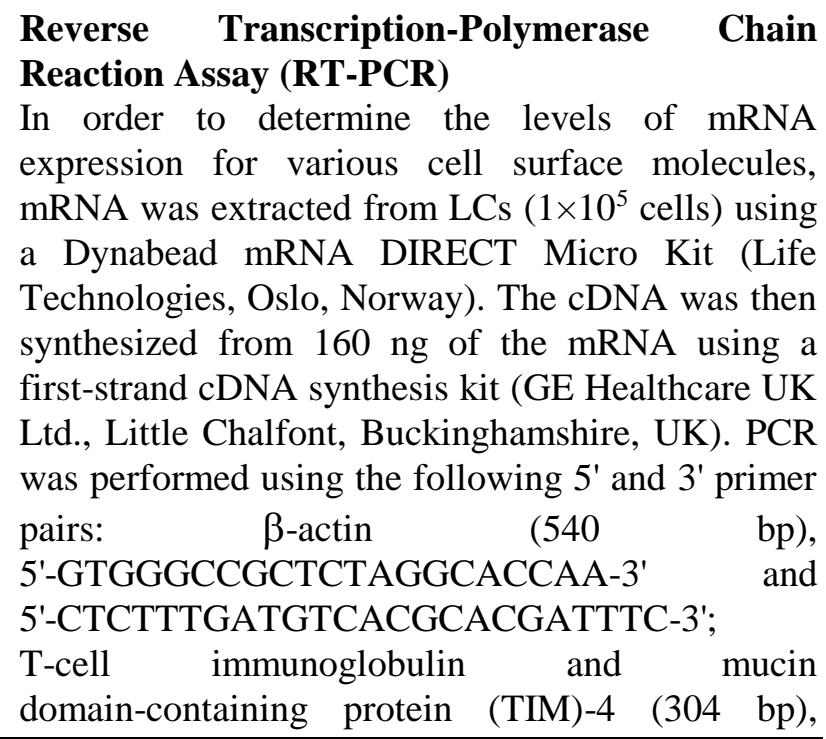


5'-GTCCAGTTTGGTGAAGTGTC-3'

and 5'-ACGTGGTCACTGCTGTACTG-3'; CD40 (295 bp), 5'-CCTGTAAGGAAGGACAACAC-3' and 5'-ATCACGACAGGAATGACCAG-3'; CD80 (312 bp), 5'-GAAGACCGAATCTACTGGCA-3' and 5'-GGAAGCAAAGCAGGTAATCC-3'; CD86 (302 bp), 5'-AGCCTGAGTGAGCTGGTAGT-3' and 5'-CCTGTTACATTCTGAGCCAG-3'; Delta 1 (318 bp), 5'-TGCACTGACCCAATCTGTCT-3' and 5'-CTCACAGTTGGCACCTGTAT-3'; Delta 3 (331 bp), 5'-CTACTGTGAAGAGCCTGATG-3' and 5'-ACAGACATAGGCAGAGTCAG-3'; $\begin{array}{llll}\text { Delta } & 4 & (307 & \text { bp }) \text {, }\end{array}$ 5'-TCACCAGACTGAGCTACTCT-3' and 5'-ATGCTGCAGGTGCCATGGAT-3'. Each PCR was performed using a GeneAmp PCR System 9700 (Perkin-Elmer, Norwalk, CT, USA) in $25 \mu \mathrm{L}$ of reaction mixture comprising $1.5 \mu \mathrm{L}$ cDNA (corresponding to $16 \mathrm{ng}$ of mRNA starting material), $200 \mu \mathrm{M}$ deoxynucleotide triphosphate mixture, $400 \mathrm{nM}$ each PCR primer and $25 \mathrm{U} / \mathrm{mL}$ Ex Taq DNA polymerase (Takara, Shiga, Japan). The reaction conditions were as follows: one 4-min cycle at $94{ }^{\circ} \mathrm{C}, 35$ cycles comprising $45 \mathrm{~s}$ at $94{ }^{\circ} \mathrm{C}$, $45 \mathrm{~s}$ at $61{ }^{\circ} \mathrm{C}$ and $2 \mathrm{~min}$ at $72{ }^{\circ} \mathrm{C}$, followed by one 7 -min cycle at $72{ }^{\circ} \mathrm{C}$, and the PCR products were separated on $2 \%$ agarose gel containing ethidium bromide.

\section{Th1 Cell and Th2 Cell Regulation by} Anti-Allergy Drugs-Treated LCs

Th1/Th2 cell regulation by LCs was investigated as described previously (9). Briefly, LCs were adjusted to $2 \times 10^{5}$ cells $/ \mathrm{mL}$ in RPMI 10 and then incubated with $6 \mu \mu \mathrm{M}$ OVA peptide (323-ISQAVHAAHAEINEAGR-339; obtained from Operon Biotechnologies, Tokyo, Japan) in the presence or absence of 5-50 $\mu \mathrm{M}$ each anti-allergy drug at $37^{\circ} \mathrm{C}$ in a humidified atmosphere with $5 \%$ $\mathrm{CO}_{2}$. The cells were collected after incubation for $18 \mathrm{~h}$, washed in RPMI 1640, and injected at a dose of $5 \times 10^{4}$ cells into both hind footpads of DO 11.10 TCR Tg mice. After 5 days, popliteal lymph nodes were harvested and then adjusted to $1 \times 10^{6}$ cells $/ \mathrm{mL}$ in RPMI 10. The cultures $(0.2 \mathrm{~mL} /$ well $)$ were incubated in 96-well culture plates (Nunc, Roskilde, Denmark) in the presence of Dynabeads Mouse T-Activator $\quad$ CD3/CD28 (5 $\mu \mathrm{L} /$ well; $\quad$ Life Technologies, Oslo, Norway) at $37^{\circ} \mathrm{C}$ in a humidified atmosphere with $5 \% \mathrm{CO}_{2}$. The culture supernatants were collected after incubation for 48 $\mathrm{h}$, and the interferon (IFN)- $\gamma$ and IL-4 concentrations were measured using enzyme-linked immunosorbent assay (ELISA) kits for quantification of murine IFN- $\gamma$ and IL-4, respectively (R \& D Systems, Minneapolis, MN, USA). Each culture was prepared in triplicate, and the mean value was obtained as a representative result for one experiment.

\section{Topical Application of Emedastine to NC/Nga Mice with AD-Like Skin Lesions and Measurement of Skin Severity Score}

AD-like skin lesions were induced in NC/Nga mice and the therapeutic effects of emedastine were assessed by measurement of the skin severity scores as described previously (13). Briefly, the abdominal hair of NC/Nga mice was shaved, then $100 \mu \mathrm{L}$ of $5 \% \quad 2,4$, 6-trinitrochlorobenzene (TNCB) dissolved in an ethanol and acetone mixture (4:1) was applied topically to the abdominal skin $\left(80 \mu \mathrm{L} / 8 \mathrm{~cm}^{2}\right.$ skin) and hind footpads (10 $\mu \mathrm{L} /$ each footpad). Four days after sensitization, the dorsal side of the ears (10 $\mu \mathrm{L} / \mathrm{each}$ ear) and the shaved dorsal skin $(80 \mu \mathrm{L} / 8$ $\mathrm{cm}^{2}$ skin) were challenged with $100 \mu \mathrm{L}$ of $0.8 \%$ TNCB dissolved in an olive oil and acetone mixture (4:1). After the first challenge, $0.8 \%$ TNCB was repeatedly applied to the same area of the skin a further 5 times at intervals of 1 week. After 4 days of the second $0.8 \%$ TNCB challenge, vehicle, $0.1 \%(\mathrm{w} / \mathrm{w})$ betamethasone ointment and $0.1 \%$ (w/w) emedastine ointment were applied topically to the dorsal side of the ears and the dorsal skin $\left(50 \mathrm{mg} /\right.$ body [ $\left.\left.=50 \mathrm{mg} / 10 \mathrm{~cm}^{2} \mathrm{skin}\right]\right)$ in each group once per day for a total of 29 days. TNCB and betamethasone were purchased from Tokyo Chemical Industry (Tokyo, Japan). White petrolatum including $5 \%(\mathrm{w} / \mathrm{w})$ liquid paraffin was used as the vehicle, and betamethasone ointment and emedastine ointment were prepared. The drug concentration in the betamethasone ointment was equal to that used in clinical practice $[=40 \sim 50 \mathrm{mg}$ of $0.12 \%(\mathrm{w} / \mathrm{w})$ betamethasone ointment $/ 10 \mathrm{~cm}^{2}$ skin/day]. The severity of dermatitis was assessed macroscopically according to the scoring system described below. One skin lesion on each ear, and one on the back, were scored on the basis of the following criteria. The dermatitis score (minimum 0 ; maximum $30[=3$ regions $\times 2$ points $\times 5$ symptoms]) was defined as the sum of the individual scores for the three regions, and graded 
as 0 (no symptoms), 1 (less than $1 / 3$ of the skin area) or 2 (1/3 and more of the skin area), for each of the following 5 symptoms: redness/scratch marks, edema/lichenification/thickening, hemorrhage/scabbing, erosion, and desquamation.

\section{Measurement of Serum Total IgE Levels}

Blood specimens were collected from the heart 29 days after assessment of skin lesion severity. The concentration of total IgE in serum was measured by ELISA using a mouse IgE ELISA kit (Cedarlane, Ontario, Canada).

\section{Quantification of Th1 and Th2 Cytokine Production from $T$ Lymphocytes in Lymph Nodes}

Auricular lymph node cells were harvested on the 29th day of assessment of skin severity, and adjusted to $1 \times 10^{6}$ cells $/ \mathrm{mL}$ in RPMI 10 . The cultures $(0.2 \mathrm{~mL} /$ well $)$ were incubated in 96 -well culture plates (Nunc) in the presence of Dynabeads Mouse T-Activator CD3/CD28 (5 $\mu \mathrm{L} /$ well; Life Technologies) at $37^{\circ} \mathrm{C}$ in a humidified atmosphere

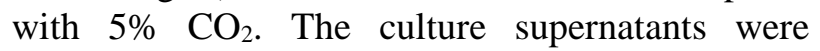
collected after incubation for $48 \mathrm{~h}$, and the IFN- $\gamma$ and IL-4 concentrations were measured using ELISA kits for quantification of murine IFN- $\gamma$ and IL-4, respectively ( $\mathrm{R} \& \mathrm{D}$ Systems). Each culture was prepared in triplicate, and the mean value was obtained as a representative result for one experiment.

\section{STATISTICAL ANALYSIS}

The data were expressed as means ( \pm SD), and differences between means were analyzed by the Tukey-Kramer multiple comparison test. Differences at $P<0.05$ were considered to be statistically significant.

\section{RESULTS}

\section{Effects of Anti-Allergy Drugs on TIM-4 mRNA Expression in LCs}

In order to predict the inhibitory effects of anti-allergy drugs on Th2 cell development, we examined their influence on TIM-4 expression in LCs. LCs were pulsed with OVA peptide for $18 \mathrm{~h}$ in the presence or absence of leukotriene receptor antagonists, a Th2 cytokine inhibitor, mediator release inhibitors, a thromboxane $\mathrm{A}_{2}$ synthesis inhibitor, a thromboxane $\mathrm{A}_{2}$ receptor antagonist, $\mathrm{H}_{1}$ blockers, and second-generation $\mathrm{H}_{1}$ receptor antagonists, respectively, and expression of mRNA for a cell surface molecule, TIM-4, was investigated using RT-PCR. As shown in Figure 1, since it was confirmed that cyproheptadine as a piperidine $\mathrm{H}_{1}$ blocker, promethazine as a phenothiazine $\mathrm{H}_{1}$ blocker, emedastine and loratadine as second-generation $\mathrm{H}_{1}$ receptor antagonists but not other anti-allergy drugs, inhibited the expression of TIM-4 mRNA in LCs, these 4 anti-allergy drugs - cyproheptadine, promethazine, emedastine and loratadine - were selected as candidate inhibitors of $\mathrm{Th} 2$ cell development.

\section{Effects of Anti-Allergy Drugs on Th1 Cell and Th2 Cell Development Through LCs}

LCs were pulsed with OVA for $18 \mathrm{~h}$ in the presence or absence of cyproheptadine, promethazine, emedastine and loratadine, respectively. The LCs were washed and injected into the hind footpads of DO 11.10 TCR Tg mice, and popliteal lymph node cells were harvested 5 days later. Subsequently, T-lymphocytes in the lymph nodes cells obtained were stimulated for 48 $\mathrm{h}$ through their surface CD3/CD28 molecules, and IFN- $\gamma$ and IL-4 concentrations in the culture supernatants were determined by ELISA. As shown in Figure 2, LCs treated with each anti-allergic drug induced inhibition of Th2 cell development in a dose-dependent manner, as represented by suppression of IL-4 production. Furthermore, emedastine inhibited Th1 cell development, also as represented by suppression of IFN- $\gamma$ production. Therefore, emedastine was finally selected as the most effective therapeutic agent for AD.

\section{Effects of Emedastine on Expression of mRNA for Cell Surface Molecules in LCs}

In order to clarify the inhibition mechanisms of Th1 cell development via emedastine-treated LCs, LCs were pulsed with OVA for $18 \mathrm{~h}$ in the presence or absence of cyproheptadine, promethazine, emedastine and loratadine, respectively, and expression of mRNA for the cell surface molecules CD40, CD80, CD86, Delta 1, Delta 3 and Delta4 was investigated using RT-PCR. As shown in Figure 3, LCs treated with emedastine inhibited the expression of CD40 mRNA, but did not influence that of other mRNAs. Also, cyproheptadine, promethazine and loratadine did not affect the expression of any of the mRNAs. 
Therapeutic Effects of Topically Applied Emedastine on TNCB-Induced AD-Like Skin Lesions

Assessment of skin lesion severity in NC/Nga mice sensitized with 5\% TNCB was started 4 days after the second challenge with $0.8 \%$ TNCB. The clinical skin lesion severity in the TNCB-sensitized mice increased gradually with time (Figure 4). All mice in the positive control group (TNCB only) exhibited AD-like skin lesions comprising redness/scratch marks, edema/ lichenification/thickening, hemorrhage/scabbing, erosion and desquamation. However, in the negative control mice (untreated), no superficial lesions were observed throughout the experimental period (data not shown). After 8 days of assessment, the therapeutic efficacy of $0.1 \%$ emedastine ointment became apparent and persisted throughout the experimental period. However, its efficacy was not as marked as that of $0.1 \%$ betamethasone ointment. On the other hand, topical application of vehicle only had no effect on the development of dermatitis.
(A)

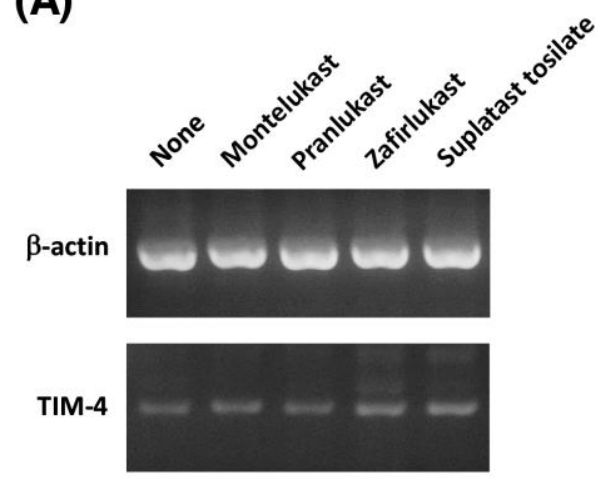

(D)

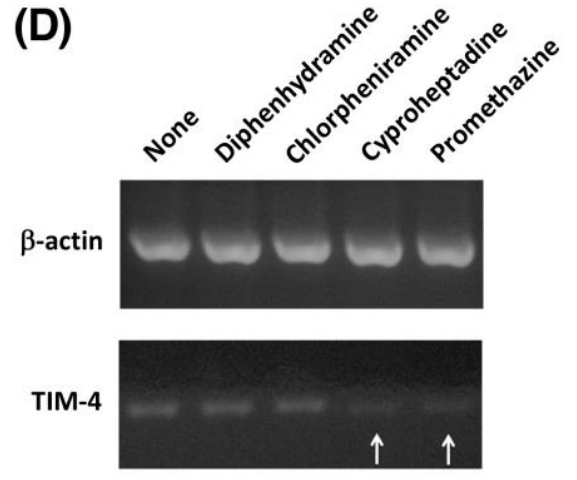

(B)

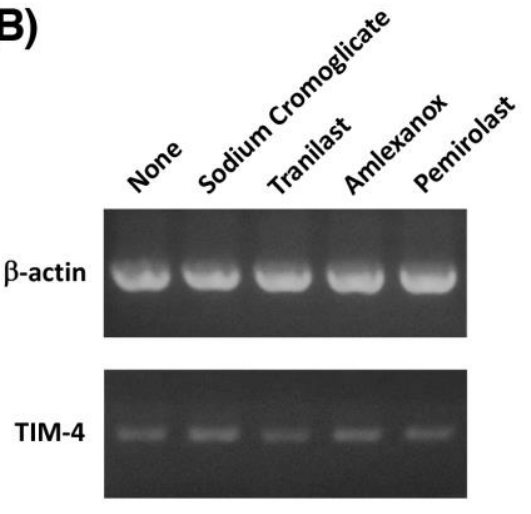

(C)

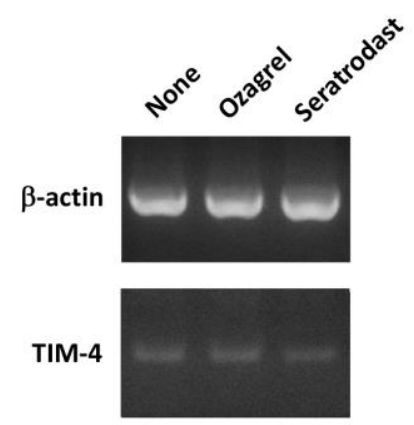

(E)

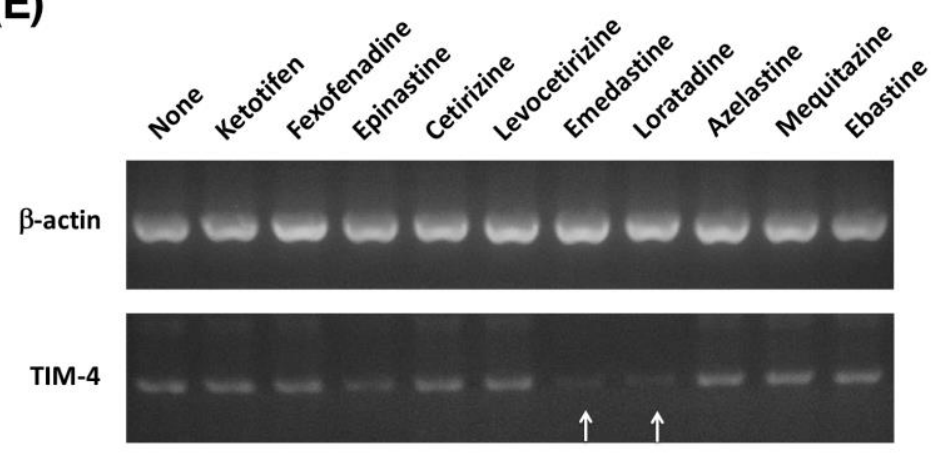

Figure 1. Effects of anti-allergy drugs on expression of TIM-4 mRNA in LCs. LCs were pulsed with OVA peptide for $18 \mathrm{~h}$ in the presence or absence of leukotriene receptor antagonists $(\mathrm{A} ; 50 \mu \mathrm{M})$, a Th2 cytokine inhibitor $(\mathrm{A} ; 50 \mu \mathrm{M})$, mediator release inhibitors $(B ; 50 \mu \mathrm{M})$, a thromboxane $A_{2}$ synthesis inhibitor $(C ; 50 \mu \mathrm{M})$, a thromboxane $A_{2}$ receptor antagonist $(\mathrm{C} ; 50 \mu \mathrm{M}), \mathrm{H}_{1}$ blockers $(\mathrm{D} ; 50 \mu \mathrm{M})$, and second-generation $\mathrm{H}_{1}$ receptor antagonists $(\mathrm{E} ; 50 \mu \mathrm{M}$, however, 5 $\mu \mathrm{M}$ for azelastine, mequitazine and ebastine). Cytoplasmic mRNA was extracted from the LCs, reverse-transcribed, and amplified by PCR using $\beta$-actin and TIM-4 primer sets. The data shown are the representative results (Experiment 2 ) of four independent experiments $(n=4)$. 

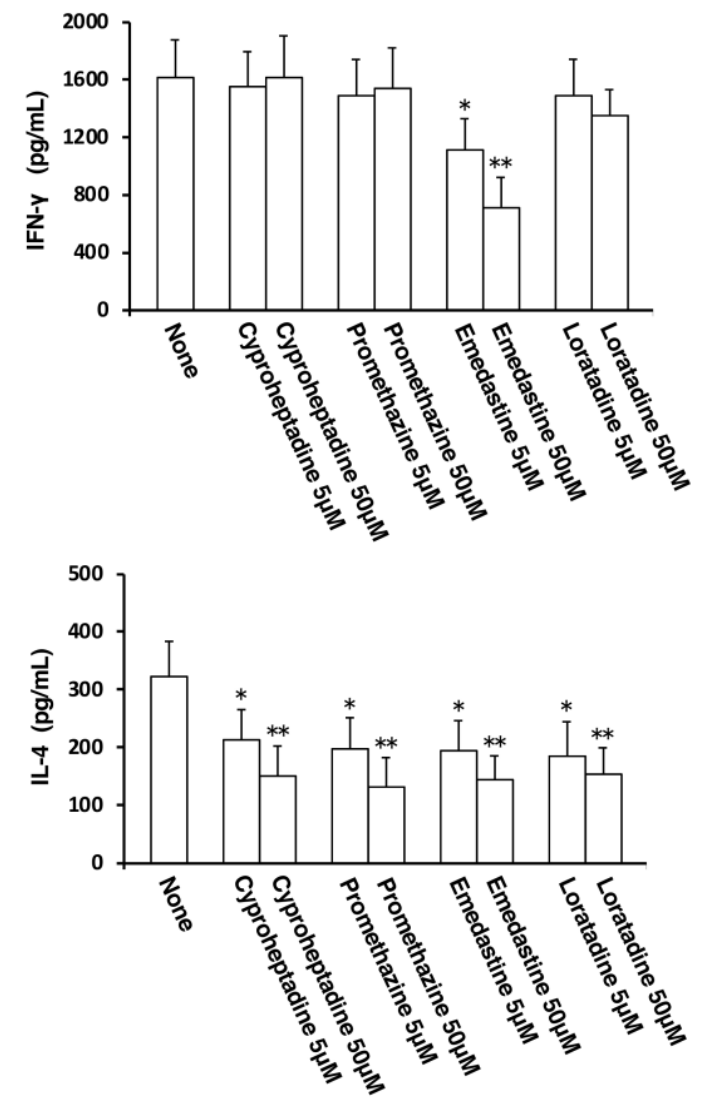

Figure 2. Effects of anti-allergy drugs on Th1 cell and Th2 cell development mediated by LCs. LCs were pulsed with OVA peptide for $18 \mathrm{~h}$ in the presence or absence of 5-50 $\mu \mathrm{M}$ anti-allergy drugs. The OVA peptide-pulsed LCs were injected into the hind footpads of mice, and popliteal lymph node cells were harvested 5 days later. The lymph node cells were stimulated through their surface CD3/CD28 molecules, and the concentrations of IFN- $\gamma$ and IL-4 in the culture supernatants were determined by ELISA. The results are expressed as means $\pm \mathrm{SD}(\mathrm{n}=6) . * P<0.05, * * P<0.01 v s$ non-treatment.

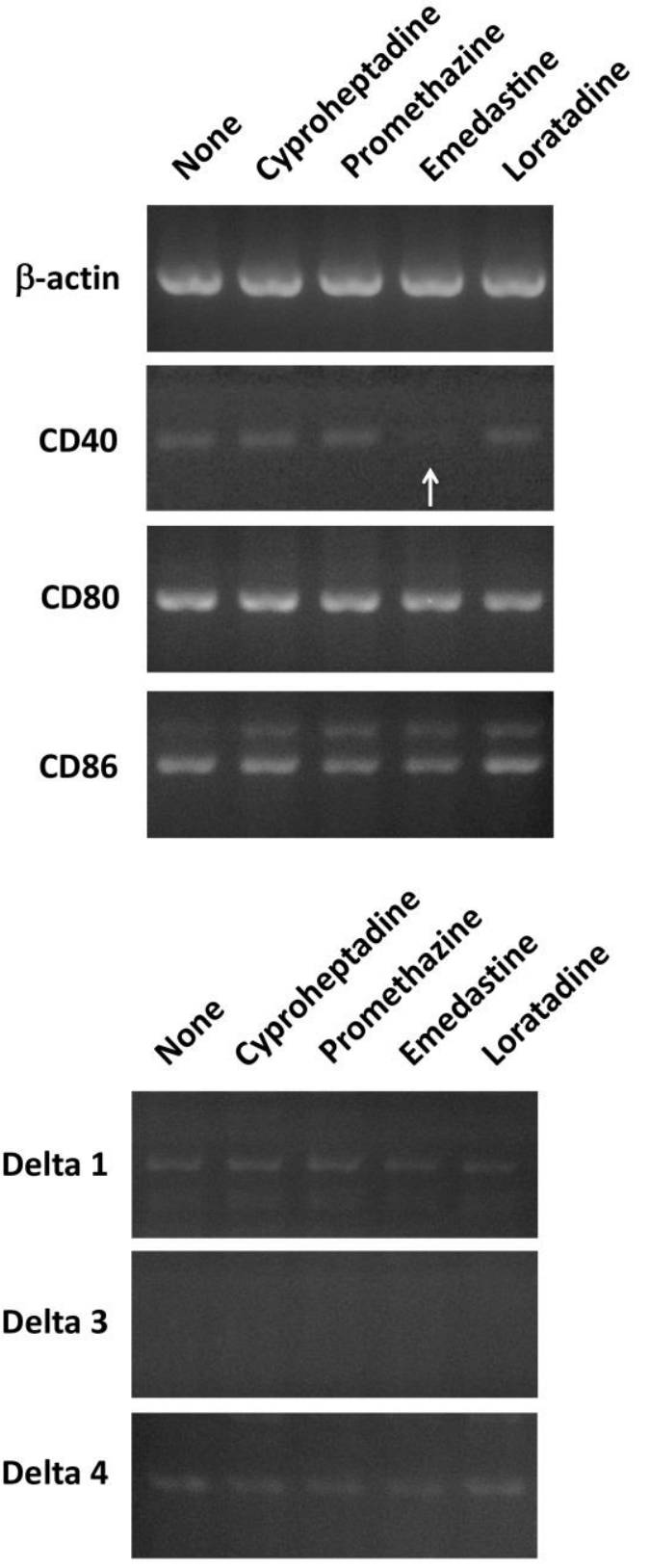

Figure 3. Effects of anti-allergy drugs on expression of cell surface molecule mRNA in LCs. LCs were pulsed with OVA peptide for $18 \mathrm{~h}$ in the presence or absence of $50 \mu \mathrm{M}$ anti-allergy drugs. Cytoplasmic mRNA was extracted from the LCs, reverse-transcribed, and amplified by PCR using primer sets for $\beta$-actin, CD40, CD80, CD86, Delta 1, Delta 3 and Delta 4. The data shown are the representative results (Experiment 4 ) of four independent experiments $(n=4)$. 


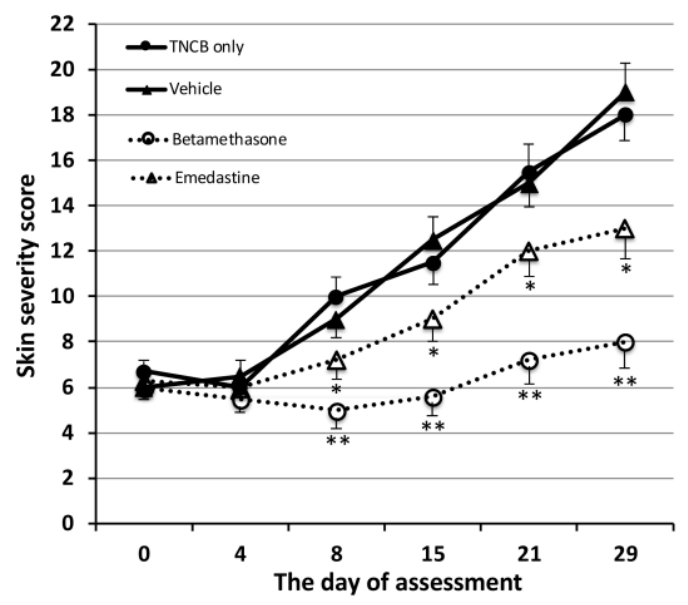

Figure 4. Effects of topical application of betamethasone and emedastine on skin severity score. The results for each experimental group are expressed as means \pm SD $(\mathrm{n}=6) . * P<0.05, * * P<0.01$ versus TNCB only.

\section{Effects of Topical Application of Emedastine on Serum Total IgE Levels}

Serum total IgE levels on the 29th day of assessment of skin lesion severity were significantly elevated in positive control mice (TNCB only) (Figure 5). Although the increased concentration of IgE in serum was not reduced by topical application of vehicle, it was reduced significantly by application of betamethasone ointment and emedastine ointment, respectively. However, the level of reduction elicited by emedastine ointment was also inferior to that elicited by betamethasone ointment.

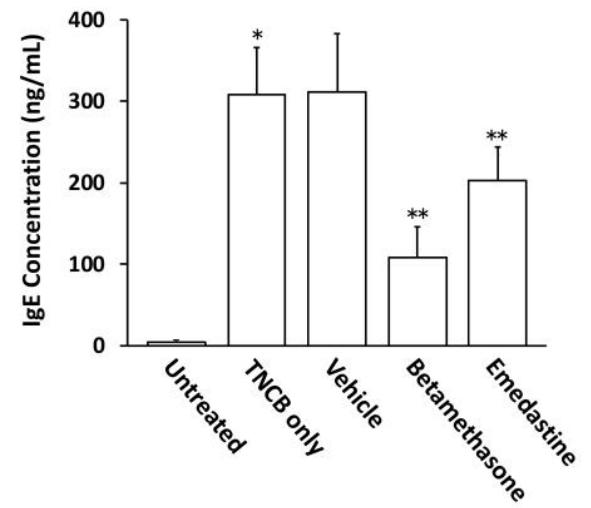

Figure 5. Quantification of $\operatorname{IgE}$ concentration in the serum of NC/Nga mice with AD-like skin lesions. The serum total IgE levels on the 29th day of assessment were measured by ELISA. The results for each experimental group are expressed as means $\pm S D(n=6)$. $* P<0.01$ versus untreated, $* * P<0.05$ versus TNCB only.
Effects of Topical Application of Emedastine on IFN- $\gamma$ and IL-4 Production from Auricular Lymph Node Cells

In order to examine the level of Th1 and Th2 cell development in auricular lymph nodes on the 29th day of assessment of skin severity, ELISA for IFN- $\gamma$ and IL-4 was carried out using culture supernatants of lymph node cells stimulated through surface CD3/CD28 molecules for $48 \mathrm{~h}$. Figure 6 shows that IFN- $\gamma$ and IL-4 production from lymph node cells was significantly increased by TNCB treatment and suppressed by treatment with emedastine ointment, but not by treatment with vehicle. However, the suppressive effect of emedastine ointment was weaker than that of betamethasone ointment.
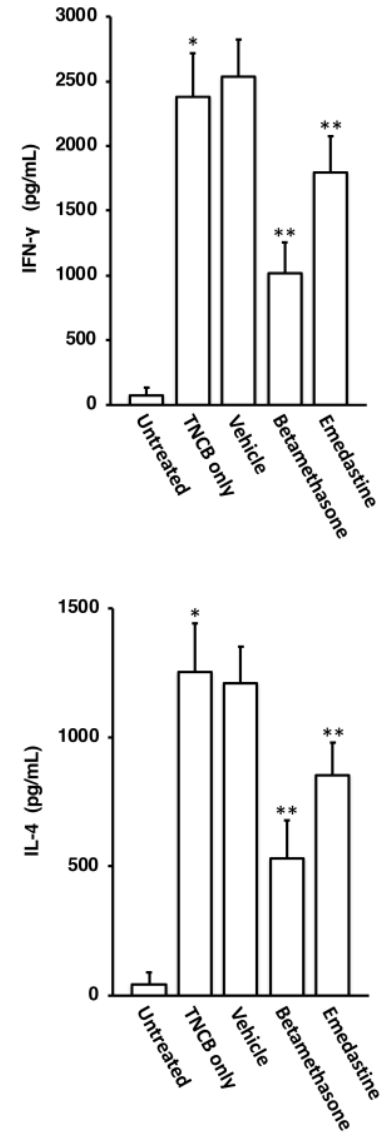

Figure 6. Effects of topical application of betamethasone and emedastine on Th1 and Th2 cytokine production from auricular lymph node cells of $\mathrm{NC} / \mathrm{Nga}$ mice with AD-like skin lesions. Auricular lymph node cells on the 29th day of assessment of skin severity were stimulated through their surface CD3/CD28 molecules, and the IFN- $\gamma$ and IL- 4 concentrations in the culture supernatants were determined by ELISA. The results are expressed as means $\pm \mathrm{SD}(\mathrm{n}=6) . * P<0.01$ versus untreated, $* * P<0.05$ versus TNCB only. 


\section{DISCUSSION}

Th1/Th2 immune balance plays a fundamental role in various immunological diseases including allergy. Many investigators have shown that Th2 immunity is responsible for allergic immune responses and the subsequent pathogenesis of allergic inflammation $(14,15)$. Contemporary lifestyle situations have led to a steady increase in the prevalence of allergies due to reduced exposure to microbial components. The quality and/or quantity of these factors is no longer sufficient to exert any significant allergy-preventing effects, leading to an imbalance of the immune system with a predisposition for development of allergic disorders (16). $\mathrm{AD}$ is one such allergic disease in which Th2 cells play an important causative role in the pathogenesis (17). This is supported by the presence of blood eosinophilia and enhanced serum levels of $\mathrm{IgE}$ in most affected patients (18). Our previous study demonstrated that drugs inhibiting Th2 cell development through LCs were therapeutically useful for $\operatorname{AD}(10,11,13)$.

In the present study, the effects of 24 anti-allergy drugs on the level of TIM-4 expression in LCs were investigated. TIM-4 is expressed by DCs including LCs, and its ligand, TIM-1, is expressed by T cells. TIM- 4 has been found to be a critical regulator of Th2 cell differentiation and is a good indicator of Th2 cell development through LCs $(9-11,19)$. The present results showed that cyproheptadine, promethazine, emedastine and loratadine each inhibited the expression of TIM-4 in LCs, suggesting that these 4 anti-allergy drugs might suppress Th2 cell development through LCs. Therefore, LCs were treated with each anti-allergy drug and injected into the hind footpads of mice. As expected, the LCs treated with each anti-allergy drug suppressed the development of Th2 cells in the popliteal lymph node cells of the mice. Furthermore, we observed that emedastine-treated LCs also suppressed the development of Th1 cells. This simultaneous inhibition of Th1 cell and Th2 cell development is important for sufficient control of the skin inflammation on AD (11). Since all anti-allergy drugs were washed out before LCs were injected, it was reasonable to assume that each anti-allergy drug had acted on LCs and changed their function.

To clarify the mechanism responsible for this down-regulation of Th1 cell development, expression of cell surface molecules other than
TIM-4 on LCs was examined. It is known that CD40 promotes the production of IL-12 from APCs and induces Th1 differentiation (20). Interaction between the CD80 and CD86 molecules on APCs and CD28 on Th cells delivers a second signal to Th cells, resulting in promotion of Th1 cell and Th2 cell development (7). In mammals, four Notch receptors, Notch 1-4, and five Notch ligands, Delta1, Delta 3, Delta 4, Jagged 1 and Jagged 2, have been identified (21). Amsen et al. (22) have presented evidence that different Notch ligands expressed on APCs direct Th1/Th2 cell differentiation in mice, and have concluded that Th1 adjuvant induces Th1 differentiation through the expression of Delta members in APCs. Our present study showed that mRNAs for CD40, CD80, CD86, Delta 1 and Delta 4 were expressed spontaneously in LCs, and that CD40 mRNA expression was suppressed by treatment with emedastine, but not with the other 3 drugs. Therefore, the inhibition of Th1 cell development through emedastine-treated LCs would be explained by inhibition of CD40 expression on LCs. The Th2 cytokine response is known to be dominant in the acute phase of $\mathrm{AD}$, and in the late phase the Th1 cytokine response is increased in addition to the Th2 cytokine response, thus contributing to chronic inflammation $(17,18,23)$. These observations indicate that topical application of emedastine can regulate both acute and chronic inflammation. In fact, we confirmed that topical application of emedastine markedly ameliorated AD-like skin lesions in $\mathrm{NC} / \mathrm{Ng}$ mice over a long period from the acute phase to the late phase. Furthermore, it was confirmed that the development of Th1/Th2 cells and the serum total $\mathrm{IgE}$ concentration, respectively, in $\mathrm{NC} / \mathrm{Ng}$ mice after treatment with emedastine ointment were significantly inhibited compared with a TNCB only group. Our previous study demonstrated that betamethasone also has superior inhibitory effects on Th1/Th2 cell development mediated by LCs and subsequent IgE production and induction of skin inflammation $(13,24)$. Although the inhibitory effects of emedastine ointment on these processes were weaker than those of betamethasone, the inhibitory effects would be increased synergistically if emedastine and betamethasone were used together. Otherwise, a higher concentration of emedastine might be used in the ointment. 


\section{CONCLUSUIONS}

Since emedastine is administrated orally in a clinical setting, its immunomodulatory effects may not reach LCs in the lesional skin. However, topical application of emedastine would enable LCs to be directly stimulated at a practically sufficient concentration, thus controlling allergen-specific Th1/Th2 cell development mediated by LCs and inhibiting the Th1/Th2 immune response in addition to its superior anti-allergic effects. Thus, topical administration of emedastine, in some cases in combination with betamethasone, appears to show promise as a new therapeutic strategy for AD lesions.

\section{ACKNOWLEDGEMENTS}

This work was supported by JSPS KAKENHI Grant Number 17K08469.

\section{CONFLICTS OF INTEREST}

The authors have no conflicts of interest to declare.

\section{REFERENCES}

1. Banchereau J, Steinman RM. Dendritic cells and the control of immunity. Nature, 1998; 392: 245-252. DOI: $10.1038 / 32588$

2. Katz SI, Tamaki K, Sachs DH. Epidermal Langerhans cells are derived from cells originating in bone marrow. Nature, 1979; 282: 324-326. DOI: $10.1038 / 282324 \mathrm{a} 0$

3. De Fraissinette A, Schmitt D, Thivolet J. Langerhans cells of human mucosa. J Dermatol, 1989; 16: 255-262. DOI: 10.1111/j.1346-8138.1989.tb01261.x

4. Barrett AW, Cruchley AT, Williams DM. Oral mucosal Langerhans' cells. Crit Rev Oral Biol Med, 1996; 7: 36-58. DOI: $10.1177 / 10454411960070010301$

5. MacPherson GG, Liu LM. Dendritic cells and Langerhans cells in the uptake of mucosal antigens. Curr Top Microbiol Immunol, 1999; 236: 33-53. DOI: 10.1007/978-3-642-59951-4_3

6. Steinman R, Inaba K. Immunogenicity: role of dendritic cells. Bioessays, 1989; 10: 145-152. DOI: 10.1002/bies.950100503

7. Lanzavecchia A, Sallusto F. Dynamics of $\mathrm{T}$ lymphocyte responses: intermediates, effectors, and memory cells. Science, 2000; 290: 92-97. DOI: $10.1126 /$ science. 290.5489 .92

8. Okamoto $\mathrm{T}$, Iwata $\mathrm{S}$, Ohnuma $\mathrm{K}$, Dang $\mathrm{NH}$, Morimoto C. Histamine H1-receptor antagonists with immunomodulating activities: potential use for modulating $\mathrm{T}$ helper type 1 (Th1)/Th2 cytokine imbalance and inflammatory responses in allergic diseases. Clin Exp Immunol, 2009; 157: 27-34. DOI: 10.1111/j.1365-2249.2009.03958.x

9. Matsui K, Tamai S, Ikeda R. Effects of macrolide antibiotics on Th1 cell and Th2 cell development mediated by Langerhans cells. J Pharm Pharm Sci, 2016; 19: 357-366. DOI: 10.18433/J3Z32F

10. Matsui K, Kashima A, Motegi A. Norfloxacin, a fluoroquinolone antibiotic, inhibits Langerhans cell-mediated Th1 and Th2 cell development. J Pharm Pharm Sci, 2019; 22: 122-130. DOI: 10.18433/jpps30335

11. Matsui K, Nojima Y, Kajiwara Y, Busujima K, Mori Y. Topical application of doxycycline inhibits Th2 cell development mediated by Langerhans cells and exerts a therapeutic effect on atopic dermatitis. J Pharm Pharm Sci, 2020; 23: 86-99. DOI: 10.18433/jpps30847

12. Matsui K, Mori A, Ikeda R. Langerhans cell-like dendritic cells stimulated with an adjuvant direct the development of Th1 and Th2 cells in vivo. Clin Exp Immunol, 2015; 182: 101-107. DOI: 10.1111/cei.12671

13. Matsui K, Tachioka K, Onodera K, Ikeda R. Topical application of josamycin inhibits development of atopic dermatitis-like skin lesions in NC/Nga mice. J Pharm Pharm Sci, 2017; 20: 38-47. DOI: $10.18433 / J 3 G W 3 D$

14. Herrick CA, Bottomly K. To respond or not to respond: $\mathrm{T}$ cells in allergic asthma. Nat Rev Immunol, 2003; 3: 405-412. DOI: 10.1038/nri1084

15. Kay AB. Advances in immunology: allergy and allergic diseases - first of two parts. N Engl J Med, 2001; 344: 30-37. DOI: 10.1056/NEJM200101043440106

16. Garn H, Renz H. Epidemiological and immunological evidence for the hygiene hypothesis. Immunobiology, 2007; 212: 441-452. DOI: 10.1016/j.imbio.2007.03.006

17. Leung DY, Boguniewicz M, Howell MD, Nomura I, Hamid QA. New insights into atopic dermatitis. J Clin Invest, 2004; 113: 651-657. DOI: 10.1172/JCI21060

18. Grewe M, Bruijnzeel-Koomen CAFM, Schöpf E, Thepen T, Langeveld-Wildschut AG, Ruzicka T, Krutmann J. A role of Th1 and Th2 cells in the immunopathogenesis of atopic dermatitis. Immunol Today, 1998; 19: 359-361. DOI: 10.1016/S0167-5699(98)01285-7

19. Ruiter B, Shreffler WG. The role of dendritic cells in food allergy. J Allergy Clin Immunol, 2012; 129: 921-928. DOI: 10.1016/j.jaci.2012.01.080

20. Van Kooten C, Banchereau J. CD40-CD40 ligand. J Leukoc Biol, 2000; 67: 2-17. DOI: 10.1002/jlb.67.1.2 
21. Artavanis-Tsakonas S, Rand MD, Lake RJ. Notch signaling: cell fate control and signal integration in development. Science, 1999; 284: 770-776. DOI: $10.1126 /$ science.284.5415.770

22. Amsen D, Blander JM, Lee GR, Tanigaki K, Honjo T, Flavell RA. Instruction of distinct CD4 $\mathrm{T}$ helper cell fates by different Notch ligands on antigen-presenting cells. Cell, 2004; 117: 515-526. DOI: $10.1016 / \mathrm{S} 0092-8674(04) 00451-9$

23. Sabin BR, Peters N, Peters AT. Chapter 20: atopic dermatitis. Allergy Asthma Proc, 2012; 33 (Suppl 1): 67-69. DOI: 10.2500/aap.2012.33.3553

24. Matsui K, Tamai S, Ikeda R. Betamethasone, but not tacrolimus, suppresses the development of Th2 cells mediated by Langerhans cell-like dendritic cells. Biol Pharm Bull, 2016; 39: 1220-1223. DOI: $10.1248 / b p b . b 16-00075$

Supplementary figures for Figure 1 and Figure 3.

Cyproheptadine, promethazine, emedastine and loratadine inhibited the expression of TIM- 4 mRNA in LCs. Furthermore, LCs treated with emedastine inhibited the expression of CD40 mRNA.

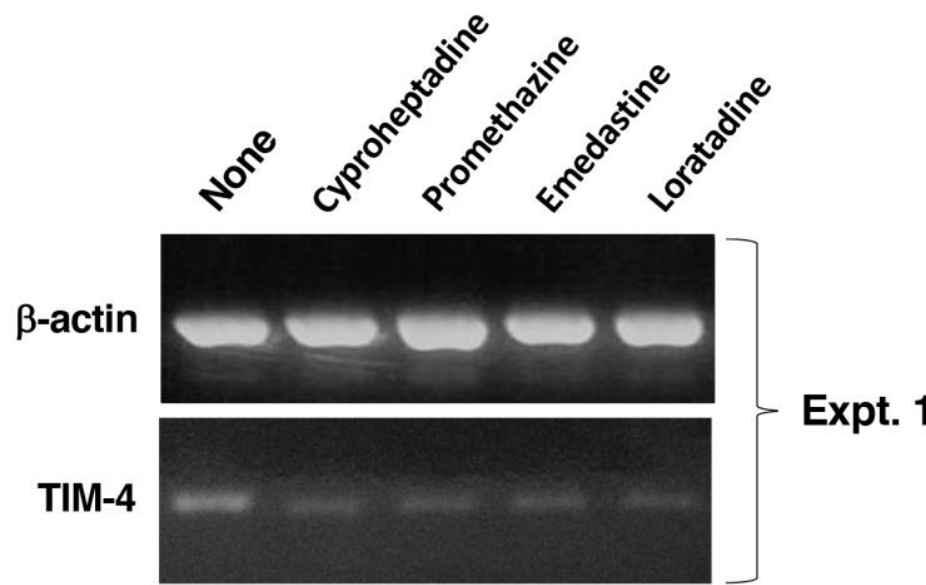

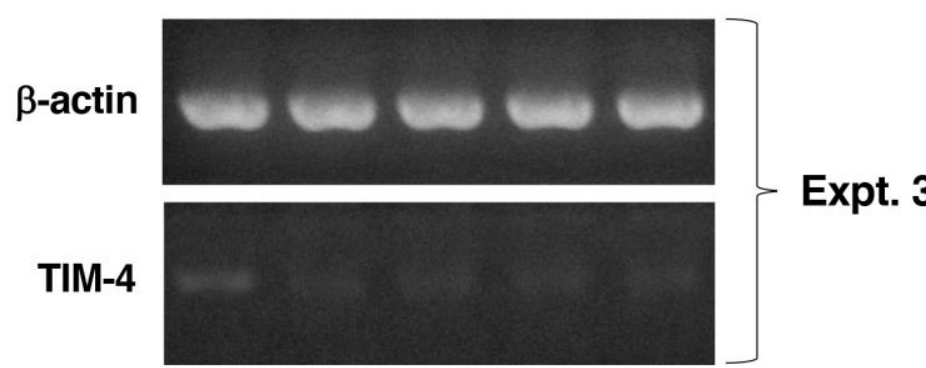

CD40

$\beta$-actin

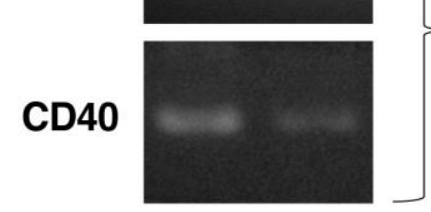

Expt. 1

$\beta$-actin

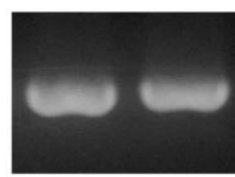

CD40

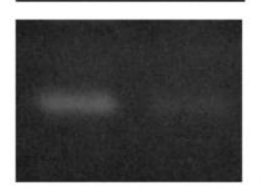

Expt. 2

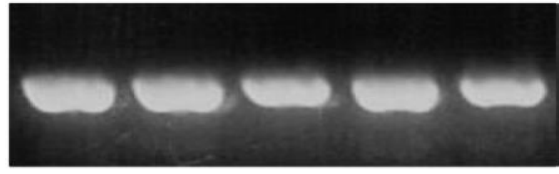

TIM-4

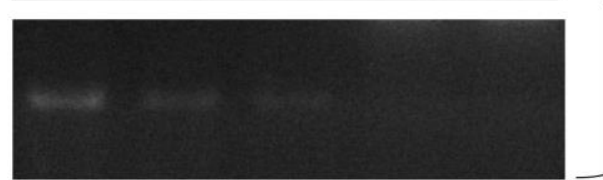

Expt. 4 $\beta$-actin

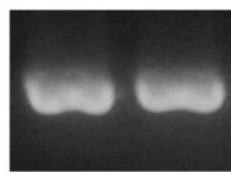

CD40

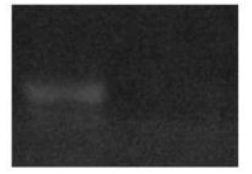

